\title{
AN ANALYSIS OF WILDFIRE RISK AND HISTORICAL OCCURRENCE FOR A MEDITERRANEAN BIOSPHERE RESERVE, CENTRAL CHILE
}

\author{
Camila BAŃALES-SEGUEL ${ }^{1}$, Francisco DE LA BARRERA ${ }^{2,3^{*}}$, Alejandro SALAZAR ${ }^{4}$ \\ ${ }^{1}$ Faculty of Agronomy and Forestry, Pontifical Catholic University of Chile, Vicuña Mackenna 4860, \\ Macul, Chile, Santiago, Chile \\ ${ }^{2}$ Department of Geography, Faculty of Architecture, Urbanism and Geography, University of Concepcion, \\ Victor Lamas 1290, Concepcion, Chile \\ ${ }^{3}$ Center for Sustainable Urban Development, Pontifical Catholic University of Chile, \\ El Comendador 1916, Providencia, Chile \\ ${ }^{4}$ Institute of Geography and Center for Sustainable Urban Development, Pontifical Catholic University of Chile, \\ Vicuńa Mackenna 4860, Macul, Chile, Santiago, Chile
}

Received 16 February 2017; accepted 29 August 2017

\begin{abstract}
Wildfires are one of the main processes that currently shape Mediterranean ecosystems. The analysis of wildfire risk combined with historical records allows for a greater understanding of trends and their relation to territorial variables that are favourable to future events. Using GIS analysis, we assess wildfire risk in La Campana - Peñuelas Biosphere Reserve, in Central Chile. Additionally, with official historical records and LANDSAT satellite images from 1985-2015 and GIS we determine historical occurrence in the Reserve. We found that the areas with very high risk of wildfire occurrence have a strong combination of ignition factors such as presence of human settlements and road connectivity, and variables that would be negatively impacted by the occurrence of wildfires, such as degraded soils and vulnerable vegetation. These findings highlight the need to destine resources to fire prevention in these areas and develop adaptation strategies for risk management at different scales.
\end{abstract}

Keywords: risk modelling, GIS, La Campana, Santiago, Valparaiso, biodiversity, periurbanization.

\section{Introduction}

Man and the Biosphere is a UNESCO scientific platform created in 1971 to improve the relationship between human beings and their environment. This platform developed the concept of Biosphere Reserve (BR), and since 1976 there have been 615 BR established in 120 countries, which seek to be representative of the different terrestrial and aquatic ecosystems of the planet (UNESCO, 2015). The BR are model regions or "laboratories for sustainability" and their aim is to combine biological conservation, socio-economic development, maintenance of cultural values, improvement of quality of life and the equitable distribution of benefits provided by the territory (Borsdorf \& Rosas, 2014).

Some of the ecosystems that have a high conservation priority are those located in Mediterranean regions. Even though these regions cover less than 5\% of Earth's surface, they host $20 \%$ of all the vascular plant species with a high level of endemism (Cowling, Rundel, Lamont, Arroyo, \& Arianoutsou, 1996). Regions with Mediterranean climate are also home to a large amount of human population, which means they have been subject to a long history of human intervention including the expansion of urban areas, land use change and deforestation (Myers, Mittermeier, Mittermeier, da Fonseca, \& Kent, 2000).

The main challenge for managing protected areas is to ensure long-term sustainability through the protection of their cultural and ecological value against predictable and unpredictable human and natural pressures (Aretano et al., 2015). One of the main forces that modify these territories is the occurrence of wildfires, being the Mediterranean ecosystems increasingly vulnerable to fire hazards in a context of climate change (Bajocco \& Ricotta, 2008; Carmona, González, Nahuelhual, \& Silva, 2012; Gill, Stephens, \& Cary, 2013; Salis, Ager, Finney, Arca, \& Spano, 2014; Darques, 2015; Levin, Tessler, Smith, \& McAlpine,

*Corresponding author. E-mail: fdelabarrera@udec.cl 
2016). Managing wildfire risk through prevention, control and restoration are vital for the integrity of ecosystems, human welfare and the stability of economic activities. In order to quantify wildfire risk and reduce its impacts, the use of tools such as geographic information systems (GIS) and remote sensing has been strongly supported by researchers and practitioners (Frau, Valenzuela, Rojas, Hernádez, \& Guajardo, 2006; Huesca, Litago, Merino-deMiguel, Cicuendez, \& Palacios, 2014).

Multiple methodologies have been developed to study the spatio-temporal distribution characterization of wildfire occurrence in order to elaborate and validate wildfire risk models (Mitsopoulos, Mallinis, \& Arianoutsou, 2014; Galiana \& Karlsson, 2012; Saglam, Bilgili, Dincdurmaz, Kadiogulari, \& Kücük, 2008; Verbesselt, Fleck, \& Coppin, 2002). Given that Mediterranean areas are highly populated, it is of outmost importance to characterize the urbanrural interface to identify the wildfires' risk and potential effects considering the human dimension (Herrero, Jappiot, Bouillon, \& Long, 2012; Darques, 2015, 2016). This characterization must consider not only structural aspects of the territory, such as roads and urban centers, but also the landscape features in which these aspects are configured, such as topography, fuel load and type, and past occurrence of fires. For example, Alloza et al. (2006) developed a vulnerability model for a Spaniard Mediterranean region using data on historical occurrence complemented with aerial photography and satellite imagery. They validated the model through field testing and using NDVI (Normalized Differential Vegetation Index) as proxy for vegetable biomass (Duguy et al., 2012). In southern Italy, Aretano et al. (2015) proposed an integrated decisionmaking model, based on GIS, which allows to identify (1) the areas of highest vulnerability that require specific protection measures and (2) the most effective management interventions to reduce vulnerability of the system toward wildfires. These authors used a number of suitable indicators that were selected to discriminate between different levels of sensitivity and pressure.

\section{Construction of wildfire risk models}

Conceptually, the wildfire risk estimation consists of identifying variables that contribute to the occurrence of a fire - such as the presence of flammable vegetation and its proximity to ignition sources - and their integration in a mathematical expression that results in a quantitative index. This task, apparently simple, has been approached in multiple ways (De Vicente, 2012). There is no consensus on key definitions such as risk, threat, and vulnerability. The present study considers risk as the product of threat and vulnerability, the first being a combination of external pressures, and the second an intrinsic condition of the territory.

The construction of an index for this purpose varies according to the focus and approach to the issue, but fundamentally it must provide quantitative information that facilitates decision-making. As is reported by van Wilgen, le Maitre, and Kriger (1985), a fire risk index must reflect the particularities of the territory that is being analyzed, incorporating different variables according to their relevance to the place and scale of application.

In relation to the spatial-temporal characterization of wildfire risk, Chuvieco and Kasischke (2007), indicate that baseline information must include: (1) historical patterns of burnt surface; (2) location of transport, residential and service infrastructure; (3) type of vegetation and fuel load; (4) fuel conditions, in particular moisture content; (5) topography; (6) potential damage to landscape and objects of value and (7) impact on vegetation, erosion and other environmental aspects. Once these variables are integrated, the validation of the wildfire risk index should be done ideally with field data for long time series (Chuvieco et al., 2004). When such records are not available, two of the most widely used and accepted methods in the literature are remote sensing and historical occurrence data (Pedernera \& Julio, 1999; Verbesselt et al., 2002).

Wildfire risk models developed for mediterranean zones have been tested in areas different to those for which they were originally designed, but without the same results, since they don't reflect the particular characteristics of the vegetation, nor the high heterogeneity of Mediterranean landscapes (Ager, Preisler, Arca, Spano, \& Salis, 2014). Arca et al. (2007) also suggest that sitespecific models give more reliable and precise predictions.

In Chile, the fire regime has grown in the last years as a consequence of the increment in the area of flammable species planted, some of them affecting urban areas close by, despite of fire prevention systems, mostly focused in areas of accumulation of high fuel load (Úbeda \& Sarricolea, 2016).

\section{Wildfire risk modelling in Chile}

Some studies conducted in Chile emphasize the role of climatic variables such as relative humidity and wind velocity on fire ignition (Julio, 1990), while others highlight the anthropogenic drivers that dominate land-use change processes, such as the expansion of forest plantations, forest regeneration and agricultural plot abandonment (Carmona et al., 2012). For central Chile Castillo, Quintanilla, and Julio (2009) studied the risk and vulnerability to fires in the rural-urban interface of the Valparaíso province where many urban and populated areas exist. Starting from georeferenced records of fire ignition, obtained from the Fire Management Department of the Forest Service (CONAF), these authors determined that fires are concentrated in areas of road connectivity and sectors dominated by deep ravines. Afterward, they elaborated a model to quantify the vulnerability to fires, which was applied to the communes of Viña del Mar and Valparaíso (Castillo, Molina, Rodríguez y Silva, \& Alvear, 2013), with a higher precision for the most heavily populated areas of the region. 
In Chile, there are ten biosphere reserves (BR) representing $45 \%$ of the terrestrial ecosystems of the country (Moreira \& Troncoso, 2014). La Campana - Peñuelas is the only BR located in the Mediterranean zone and belonging to the biodiversity hotspot of central Chile (Myers et al., 2000). This BR is in a dynamic scenario of territorial transformation, where land-use change tendencies are conjugated with social interactions characteristic of the rural-urban interface and with the periodic occurrence of wildfires.

According to CONAF, the greatest surface affected by fires in Chile is burnt during the summer months of December, January and February (14\%, 31\% and 31\% respectively). The administrative units (communes) most affected by wildfires in the La Campana - Peñuelas BR are Quilpué, Valparaíso, Casablanca and Limache. In the last 30 years, the total surface burnt has decreased, but the relative contribution of forest plantations to the surface affected by wildfires has increased (CONAF, 2015).

Even though the La Campana - Peñuelas BR was created in 1984, its Management Plan and associated zoning were approved only in 2009 (Salazar \& Moreira, 2014). The territory where this BR is located has been subject to important historical changes in land use and land cover. These changes are characterized by an expansion of urban limits and the expansion of forestry plantations in the last decades.

The tendencies of land use change in central Chile have had a profound impact on ecosystem services (Venegas, 2015), which have a synergic effect with the damage caused by fires. Some researchers have proposed that the occurrence of fire is a significant driver for land cover change in Mediterranean areas, given that they produce an immediate and lasting effect on vegetation. Post-fire vegetation regeneration tends to be dominated by exotic species, which are often very invasive (Ireland \& Petropoulos, 2015). Also, burnt sites are more vulnerable to being burnt again due to the remaining fuel content on the ground composed of fallen and standing trunks. This is especially relevant when the wildfire had a low burn intensity, in sites that are close to urban or agricultural areas (Bajocco \& Ricotta, 2008), and where there is intense propagation of annual herbs that become dry vegetation in the summer (Luebert \& Pliscoff, 2017). The present work consists of a methodological approximation in order to identify the areas which higher wildfire risk (in relation to ignition, propagation and impact) in a Biosphere Reserve located in the Mediterranean landscapes of Chile. Using GIS and remote sensing, we design and apply a wildfire risk index, considering the available cartographic information and contrast the results to historical wildfire occurrence. The purpose of this work is to contribute with an instrument for decision making in the areas of fire prevention and control, as well as post-fire ecosystem restoration, in order to strengthen the sustainability of a region of utmost biodiversity importance.

\section{Area of study}

The Biosphere Reserve selected for the analysis of wildfire risk and occurrence was La Campana - Peñuelas BR. It has a total area of 241.000 hectares, was created in 1984 and covers a territory of 14 communes in two administrative regions (Valparaiso and Santiago) that contain almost half of the national population. (Figure 1). Enormous challenges for management stem from lack of consistency and coordination among the weak territorial planning instruments and other tools (e.g. specific management plans of protected areas) developed under multiple levels of decision-making (Figure 2) (Salazar, Moreira, \& Río, 2015). It is vital, then, to develop tools that facilitate the coordination between actors and the decision-making process.

The temporal approach chosen for quantifying wildfire risk has a long-term orientation towards decision-making related with territorial planning and reducing the negative impacts of wildfires. For this, structural risk variables that do not change, or change slowly over time were selected (De Vicente, 2012). Climate variables such as precipitation or temperature are not included for two reasons. First, they are not considered structural variables to determine long-term risk, but rather specific conditions that would better serve in a fire occurrence probability model. Second, there is a lack of representative time series for the area of study that can account for micro-climates characteristic of mountainous areas and coastal territories.

Fourteen communes are included within the BR limits, but only six account for more than half of the BR territory (Olmué, Hijuelas, Quilpué, Limache, Valparaiso and Villa Alemana; Figure 2). These six communes also cover approximately $75 \%$ of the BR area. Another commune (Casablanca) has the second largest area inside de $\mathrm{BR}$, however, its net coverage is less than half, due to its extensive territory (Figure 2). These communes are especially relevant considering they have an important role in decision-making that is decisive for the BR as a whole.

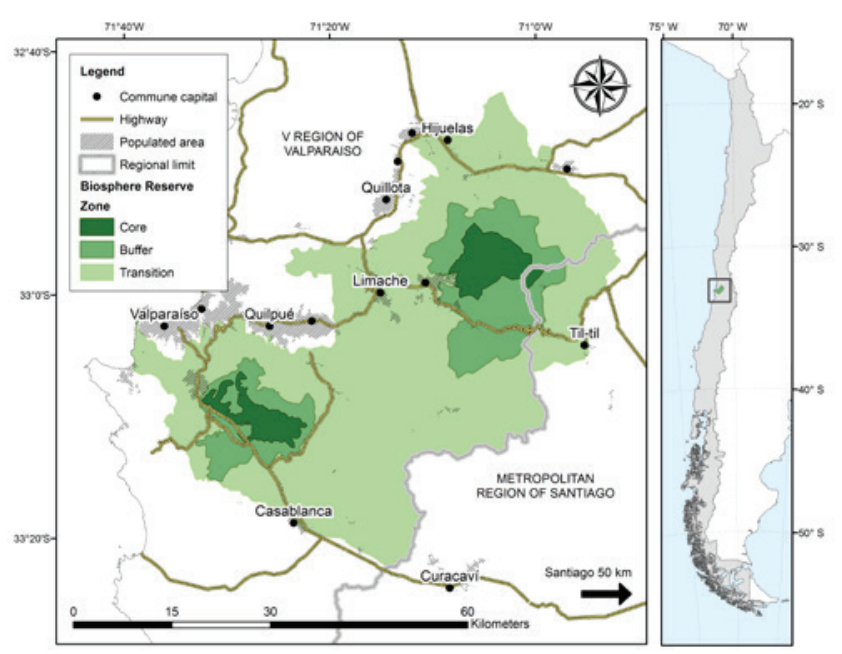

Figure 1. Biosphere Reserve Location 


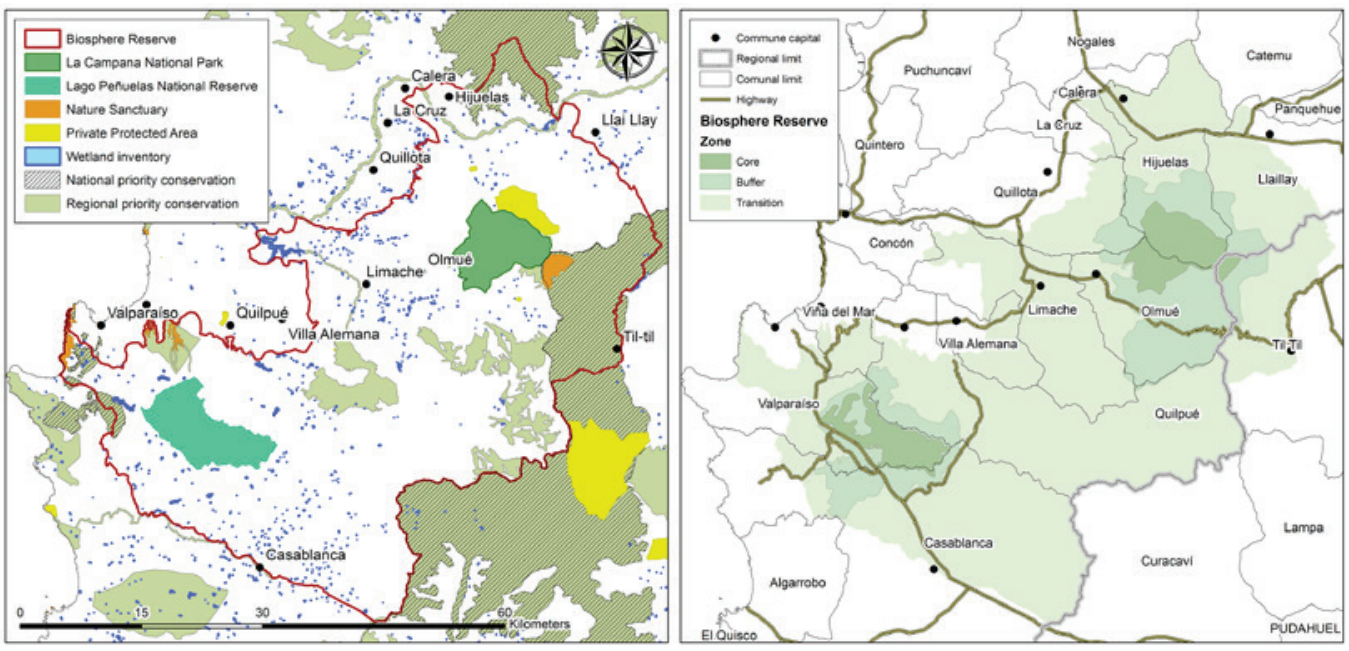

Figure 2. Conservation and administrative units within Biosphere Reserve

\section{Methods}

\subsection{Preparation of geospatial data}

The spatial information used comes from official sources (Table 1), shows vector and raster data organized using GIS. The vector data was used for the construction of maps and as input for the fire risk variables. The raster data comes from LANDSAT image processing and was used for the comparison of the index with historical occurrence as is described later on.

Table 1. Entry data for risk variables, defined in $30 \mathrm{~m}$ cells, and criteria for classification

\begin{tabular}{|c|c|c|c|c|c|}
\hline Clusters & $\begin{array}{l}\text { Risk variables } \\
\text { (reference) }\end{array}$ & $\begin{array}{l}\text { Entry data } \\
\text { (source) }\end{array}$ & $\begin{array}{l}\text { Methodology for } \\
\text { classification }\end{array}$ & Criteria for classification & Risk class \\
\hline \multirow[t]{21}{*}{ Ignition } & \multirow{7}{*}{$\begin{array}{l}\text { Roads (Sivrikaya, } \\
\text { Sağlam, Akay, } \\
\text { \& Bozali, 2014; } \\
\text { Castillo et al., 2009; } \\
\text { Pourtaghi et al., } \\
\text { 2015) }\end{array}$} & \multirow{7}{*}{$\begin{array}{l}\text { Road network } \\
\text { (Military } \\
\text { Geographic } \\
\text { Institute, Chile) }\end{array}$} & \multirow{7}{*}{$\begin{array}{l}\text { Distance from roads } \\
\text { and railroads }\end{array}$} & $0-100 \mathrm{~m}$ & 7 \\
\hline & & & & $100-200 \mathrm{~m}$ & 6 \\
\hline & & & & $200-300 \mathrm{~m}$ & 5 \\
\hline & & & & $300-400 \mathrm{~m}$ & 4 \\
\hline & & & & $400-500 \mathrm{~m}$ & 3 \\
\hline & & & & $500-600 \mathrm{~m}$ & 2 \\
\hline & & & & $>600 \mathrm{~m}$ & 1 \\
\hline & \multirow{7}{*}{$\begin{array}{l}\text { Populated areas } \\
\text { (Chuvieco \& } \\
\text { Kasischke, 2007; } \\
\text { Saglam et al., 2008; } \\
\text { De Vicente, 2012; } \\
\text { Carmona et al., } \\
2012 \text { ) }\end{array}$} & \multirow{7}{*}{$\begin{array}{l}\text { Consolidated } \\
\text { and disperse } \\
\text { populated } \\
\text { areas (National } \\
\text { Statistical } \\
\text { Institute, Chile) }\end{array}$} & \multirow{7}{*}{$\begin{array}{l}\text { Distance from } \\
\text { populated areas ( } 200 \mathrm{~m} \\
\text { buffer). Higher risk was } \\
\text { assigned to disperse } \\
\text { populated areas, based } \\
\text { on national census } \\
\text { and its hierarchical } \\
\text { definition }\end{array}$} & Locality & 7 \\
\hline & & & & Hamlet & 6 \\
\hline & & & & Village & 5 \\
\hline & & & & Town & 4 \\
\hline & & & & City & 3 \\
\hline & & & & N/A & 2 \\
\hline & & & & N/A & 1 \\
\hline & \multirow{7}{*}{$\begin{array}{l}\text { Fuel type } \\
\text { (Chuvieco, et al., } \\
\text { 2004; Salvati \& } \\
\text { Ferrera, 2014; } \\
\text { Carmona et al., } \\
\text { 2012; Castillo et al., } \\
2009 \text { ) }\end{array}$} & \multirow{7}{*}{$\begin{array}{l}\text { Maximum } \\
\text { likelihood } \\
\text { supervised } \\
\text { classification } \\
\text { from LANDSAT } \\
\text { images (US } \\
\text { Geological } \\
\text { Service) }\end{array}$} & \multirow[t]{7}{*}{ Land cover type } & Forest plantation & 7 \\
\hline & & & & Sclerophyllous shrub and forest & 6 \\
\hline & & & & Natural prairie & 5 \\
\hline & & & & Agriculture & 4 \\
\hline & & & & Thorny shrub; Xerophytic shrub & 3 \\
\hline & & & & $\begin{array}{l}\text { Wetlands; Scarce vegetation; Urban } \\
\text { vegetation }\end{array}$ & 2 \\
\hline & & & & $\begin{array}{l}\text { Urban, no vegetation; Bodies of } \\
\text { water }\end{array}$ & 1 \\
\hline
\end{tabular}




\begin{tabular}{|c|c|c|c|c|c|}
\hline Clusters & $\begin{array}{l}\text { Risk variables } \\
\text { (reference) }\end{array}$ & $\begin{array}{l}\text { Entry data } \\
\text { (source) }\end{array}$ & $\begin{array}{l}\text { Methodology for } \\
\text { classification }\end{array}$ & Criteria for classification & Risk class \\
\hline \multirow[t]{14}{*}{ Propagation } & \multirow{7}{*}{\begin{tabular}{|l|} 
Topography \\
(Sivrikaya et al., \\
2014; Alloza et al., \\
2006; Saglam et al., \\
2008; Viedma et al., \\
2008)
\end{tabular}} & \multirow{7}{*}{$\begin{array}{l}\text { ASTER Digital } \\
\text { elevation model } \\
\text { (NASA Reverb) }\end{array}$} & \multirow[t]{7}{*}{ Slope range } & $>35 \%<$ & 7 \\
\hline & & & & $30-35 \%$ & 6 \\
\hline & & & & $25-30 \%$ & 5 \\
\hline & & & & $20-25 \%$ & 4 \\
\hline & & & & $15-20 \%$ & 3 \\
\hline & & & & $10-15 \%$ & 2 \\
\hline & & & & $0-10 \%$ & 1 \\
\hline & \multirow{7}{*}{$\begin{array}{l}\text { Hydrography } \\
\text { (Carmona et al., } \\
\text { 2012; Pourtaghi } \\
\text { et al., 2015) }\end{array}$} & \multirow{7}{*}{$\begin{array}{l}\text { Continental } \\
\text { water masses, } \\
\text { rivers and } \\
\text { permanent } \\
\text { streams (General } \\
\text { Water Directory, } \\
\text { Chile) }\end{array}$} & \multirow{7}{*}{$\begin{array}{l}\text { Distance from bodies } \\
\text { of water and permanent } \\
\text { water courses }\end{array}$} & $>300 \mathrm{~m}$ & 7 \\
\hline & & & & $250-300 \mathrm{~m}$ & 6 \\
\hline & & & & $200-250 \mathrm{~m}$ & 5 \\
\hline & & & & $150-200 \mathrm{~m}$ & 4 \\
\hline & & & & $100-150 \mathrm{~m}$ & 3 \\
\hline & & & & $50-100 \mathrm{~m}$ & 2 \\
\hline & & & & $0-50 \mathrm{~m}$ & 1 \\
\hline \multirow[t]{21}{*}{ Impact } & \multirow{7}{*}{$\begin{array}{l}\text { Vegetation (BCN, } \\
\text { 2014a, 2014b, } \\
\text { 2014c; Alloza et al., } \\
\text { 2006; Hessburg, } \\
\text { Reynolds, Keane, } \\
\text { James, \& Salter, } \\
\text { 2007) }\end{array}$} & \multirow{7}{*}{$\begin{array}{l}\text { Vegetation } \\
\text { formations } \\
\text { (Luebert \& } \\
\text { Pliscoff, 2009) }\end{array}$} & \multirow{7}{*}{$\begin{array}{l}\text { Vulnerability based } \\
\text { on total national area, } \\
\text { percentage under } \\
\text { protected areas, } \\
\text { number of vulnerable } \\
\text { species }\end{array}$} & $\begin{array}{l}\text { Mediterranean interior thorny } \\
\text { forest of Acacia caven and Prosopis } \\
\text { chilensis }\end{array}$ & 7 \\
\hline & & & & $\begin{array}{l}\text { Mediterranean coastal low shrub of } \\
\text { Chuquiraga oppositifolia y Mulinum } \\
\text { spinosum }\end{array}$ & 6 \\
\hline & & & & $\begin{array}{l}\text { Mediterranean coastal deciduous } \\
\text { forest of Nothofagus macrocarpa and } \\
\text { Ribes punctatum }\end{array}$ & 5 \\
\hline & & & & $\begin{array}{l}\text { Mediterranean interior } \\
\text { sclerophyllous shrub of Quillaja } \\
\text { saponaria and Porlieria chilensis }\end{array}$ & 4 \\
\hline & & & & $\begin{array}{l}\text { Mediterranean coastal } \\
\text { sclerophyllous forest of Lithraea } \\
\text { caustica and Cryptocarya alba }\end{array}$ & 3 \\
\hline & & & & $\begin{array}{l}\text { Mediterranean coastal } \\
\text { sclerophyllous forest of Cryptocarya } \\
\text { alba and Peumus boldus }\end{array}$ & 2 \\
\hline & & & & N/A & 1 \\
\hline & \multirow{7}{*}{$\begin{array}{l}\text { Soil (CIREN, 2010a, } \\
\text { 2010b; Alloza et al., } \\
\text { 2006) }\end{array}$} & \multirow{7}{*}{$\begin{array}{l}\text { Erosion and } \\
\text { desertification } \\
\text { degree (Natural } \\
\text { Resources } \\
\text { Information } \\
\text { Center, Chile) }\end{array}$} & \multirow{7}{*}{$\begin{array}{l}\text { Combination of } \\
\text { qualitative categories } \\
\text { of desertification and } \\
\text { erosion (very high, } \\
\text { high, medium, low) }\end{array}$} & $10-12$ & 7 \\
\hline & & & & $7-9$ & 6 \\
\hline & & & & $5-7$ & 5 \\
\hline & & & & 4 & 4 \\
\hline & & & & 3 & 3 \\
\hline & & & & 2 & 2 \\
\hline & & & & 1 & 1 \\
\hline & \multirow{7}{*}{$\begin{array}{l}\text { High environmental } \\
\text { value areas (Muñoz, } \\
\text { Núñez, \& Yáñez, } \\
\text { 1997; BCN, 2010, } \\
\text { 2014c; CONAMA, } \\
\text { 2005, 2008; CNM, } \\
\text { 2010; MMA, 2011) }\end{array}$} & \multirow{7}{*}{$\begin{array}{l}\text { State and private } \\
\text { protected and } \\
\text { vulnerable } \\
\text { areas (National } \\
\text { Spatial Data } \\
\text { Infrastructure, } \\
\text { Chile) }\end{array}$} & \multirow{7}{*}{$\begin{array}{l}\text { Score based on } \\
\text { belonging to areas with } \\
\text { different restrictions } \\
\text { (national protected } \\
\text { areas, priority } \\
\text { conservation sites } \\
\text { and non-protected } \\
\text { vulnerable wetlands). } \\
\text { Overlapping areas } \\
\text { receive sum of scores }\end{array}$} & \multirow{7}{*}{$\begin{array}{l}\text { See Table } 2 \text { for definition of scores } \\
\text { for different protected areas. }\end{array}$} & 7 \\
\hline & & & & & 6 \\
\hline & & & & & 5 \\
\hline & & & & & 4 \\
\hline & & & & & 3 \\
\hline & & & & & 2 \\
\hline & & & & & 1 \\
\hline
\end{tabular}


Table 2. Criteria for scores of high conservation value areas

\begin{tabular}{|llc|}
\hline \multicolumn{1}{|c}{ Protection } & \multicolumn{1}{c|}{ Type of area } & Score \\
\hline Public, normative & National Park & 3 \\
& National Reserve & 2 \\
& Nature Sanctuary & 1 \\
Public, indicative & National priority & 1 \\
& conservation site & \\
& Regional priority & 1 \\
Private & conservation site & \\
No protection & Private Protected Area & 2 \\
\hline
\end{tabular}

\subsection{Structure of the wildfire risk index}

In order to define the variables to calculate wildfire risk, literature and available data were revised. The variables were grouped in three clusters: ignition, propagation and impact. The values for each variable were assigned a risk class from 1 to 7 based on their particularities (Table 1). Variables were combined using GIS to generate three cluster maps and then a composite wildfire risk map (Figure 4 and Figure 5). The ignition cluster considers ignition sources and fuel type. The propagation cluster is

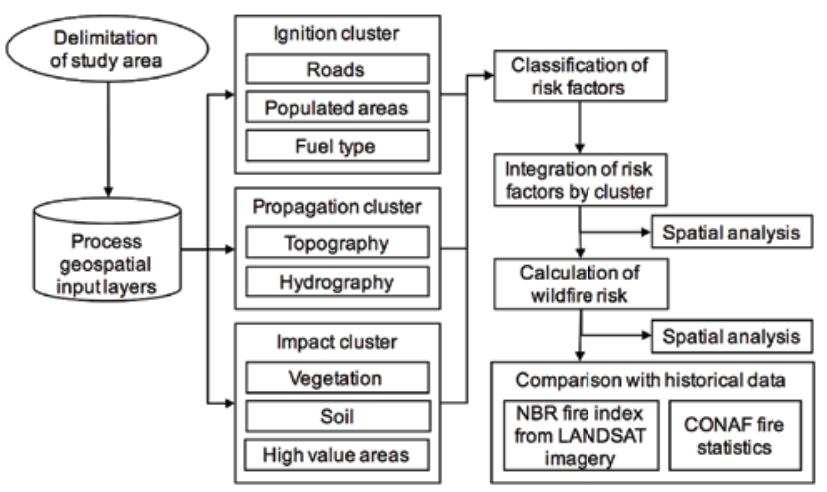

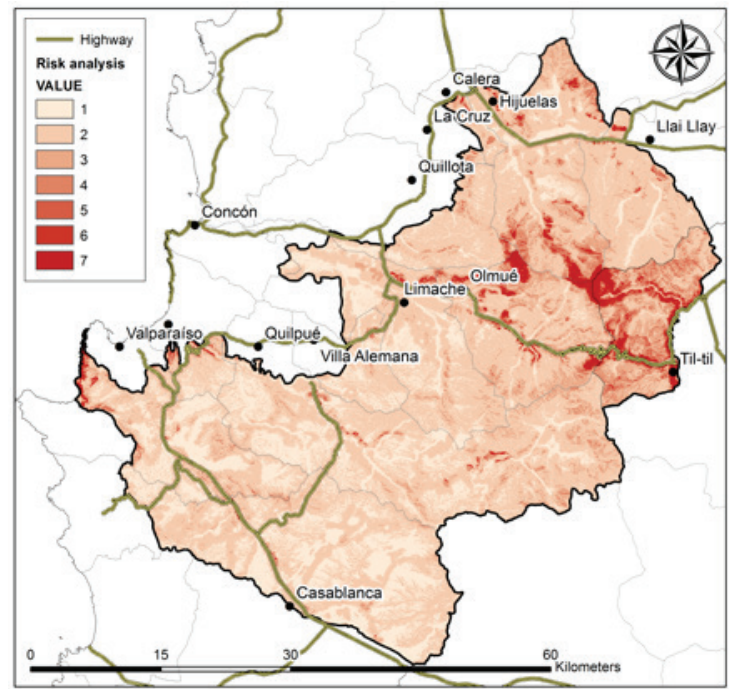

Figure 5. Wildfire risk

composed by intrinsic characteristics of the territory that affect the fire behaviour. Finally, the impact cluster considers territorial elements that would be affected and/or aggravated by the occurrence of fires.

\subsubsection{Ignition cluster}

As a transport variable, the road network was used because these have been identified as the main source of ignition due to the high traffic of people (Castillo et al., 2009). Another source of ignition are populated areas (Chuvieco \& Kasischke, 2007), for which a buffer distance and the type of populated area were chosen. Areas that are not consolidated and more disperse present a higher fire risk (Fox et al., 2015; Herrero et al., 2012; Lampin-Maillet, Long, Ganteaume, Jappiot, \& Ferrier, 2011; Bhandary \& Muller, 2009; Saglam et al., 2008). The third variable in this cluster is fuel type, which was quantified using a supervised classification of LANDSAT images between 1985 and 2015.

Figure 3. Final methodology diagram
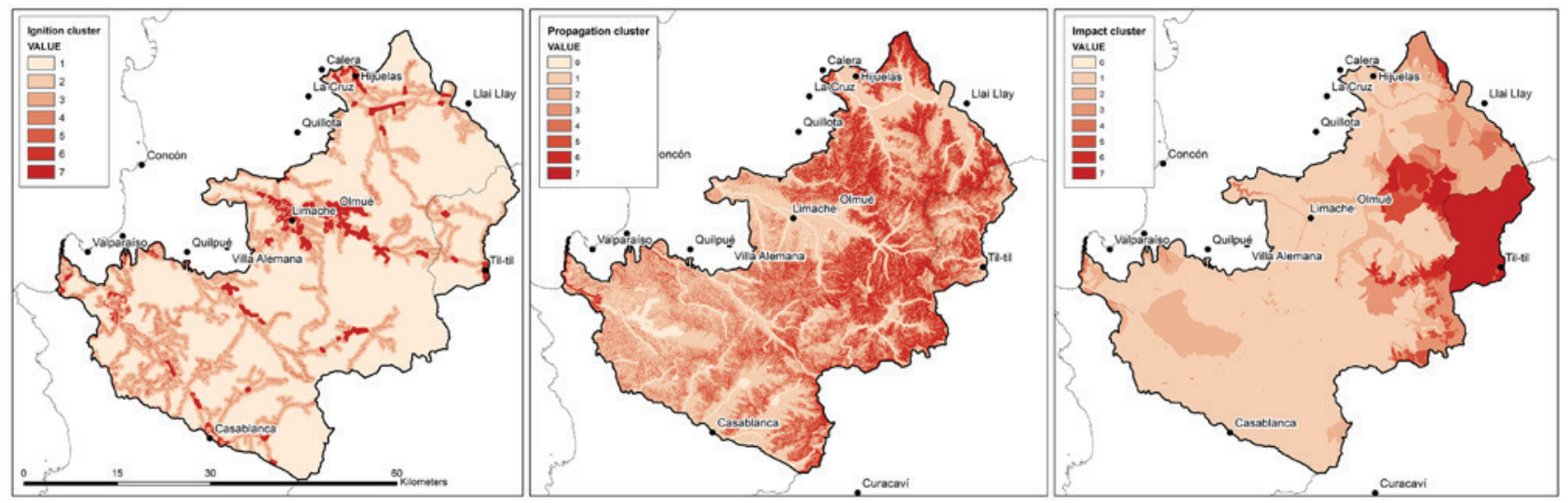

Figure 4. Three cluster maps 


\subsubsection{Propagation cluster}

The two variables that compose this cluster are topography and hydrography. The topography of a territory affects the behavior of fires inasmuch as those areas with steep slopes are favorable to the acceleration of fire propagation (Viedma, 2008). Moreover, the proximity to bodies of water prevents fires; at a greater distance fire spread is encouraged (Carmona et al., 2012). Riparian ecosystems present higher biodiversity in general than surrounding areas, making them more resilient to fires, even acting as firebreaks, as long as streams have permanent water flows.

\subsubsection{Impact cluster}

This cluster considers elements that are negatively altered by fire occurrence, such as: vegetation, soils and areas of high environmental value.

To integrate vegetation as a variable, the national characterization developed by Pliscoff and Luebert (updated in 2017) was used. The representativeness of these vegetation formations was analyzed within the BR, assigning them a hierarchal vulnerability degree based on the total national surface, the percentage under state or private protected areas and the number of species under some category of vulnerability. Thus, for example, the "Mediterranean deciduous forest dominated by Nothofagus macrocarpa and Ribes punctatum" formation has an extension of 87.355 hectares on a national level, of which 20.044 ha $(22 \%)$ are represented in protected areas. On the other hand, the formation defined as "thorny forest of Acacia caven and
Prosopis chilensis" has a national surface of 340.929 hectares, of which only 7.001 ha $(2 \%)$ are protected. Additionally, Prosopis chilensis a dominant species of this formation is listed as vulnerable (MMA, 2013), therefore receiving a higher risk value.

Regarding soils, erosion and desertification are two relevant phenomena associated to soil management in Chile. Due to extractive activities and accelerated changes in precipitation and temperature patterns, these processes are a worrying reality, especially in the central zone of Chile where the BR is located (CIREN, 2010a, 2010b). Fires aggravate both processes by leaving the earth surface devoid of vegetation and exposed to erosive factors such as wind and rain.

There are different types of protected areas within the BR, which are normed by different national organisms and have different degrees of protection and restrictions. With the purpose of comparing the different high environmental value areas present in the BR, they were assigned a score based on the type of restrictions they present (Table 3). We considered areas that are officially protected and those that are considered vulnerable and are not protected (specifically, wetlands). National Parks have the highest environmental restrictions; therefore they receive the highest value, followed by National Reserves and Nature Sanctuaries. National and Regional priority conservation sites are mere indicative definitions without strict regulations. Private protected areas were scored the same as National Reserves since they are managed under equal standards (Biblioteca del Congreso Nacional, 2010; Comité Nacional Pro Defensa de la Fauna y Flora, 1999).

Table 3. Local government units overlapping the BR and their wildfire risk

\begin{tabular}{|c|c|c|c|c|c|c|c|}
\hline \multirow[b]{2}{*}{ Commune } & \multirow[b]{2}{*}{$\begin{array}{l}\% \text { of BR Inside } \\
\text { Commune Area }\end{array}$} & \multirow[b]{2}{*}{$\begin{array}{l}\% \text { of Commune } \\
\text { Area Inside BR }\end{array}$} & \multirow[b]{2}{*}{$\begin{array}{l}\text { Average Risk } \\
\text { Class }\end{array}$} & \multicolumn{4}{|c|}{$\begin{array}{c}\% \text { of Commune Area Inside BR by Category o } \\
\text { Wildfire Risk }\end{array}$} \\
\hline & & & & $\begin{array}{l}\text { Very High } \\
(5,6,7)\end{array}$ & $\begin{array}{l}\text { High } \\
(3,4)\end{array}$ & $\begin{array}{c}\text { Medium } \\
\text { (2) }\end{array}$ & $\begin{array}{l}\text { Low } \\
(1)\end{array}$ \\
\hline Quilpué & 20.1 & 90.2 & 1.5 & 0.4 & 5.3 & 37.8 & 56.4 \\
\hline Casa Blanca & 18.1 & 45.8 & 1.2 & 0.2 & 1.6 & 20.3 & 77.9 \\
\hline Hijuelas & 11.1 & 99.9 & 2.2 & 5.9 & 17.0 & 46.7 & 30.5 \\
\hline Limache & 9.8 & 79.6 & 1.5 & 0.7 & 3.9 & 35.9 & 59.6 \\
\hline Olmué & 9.6 & 100 & 2.5 & 9.2 & 19.1 & 52.4 & 19.3 \\
\hline Valparaíso & 8.5 & 66.2 & 1.6 & 2.5 & 6.3 & 35.1 & 56.0 \\
\hline Til-til & 6.8 & 25.1 & 3.5 & 23.7 & 38.2 & 36.6 & 1.5 \\
\hline Llaillay & 6.2 & 42.9 & 1.8 & 1.5 & 4.7 & 64.2 & 29.6 \\
\hline Quillota & 4.4 & 35.4 & 1.6 & 1.2 & 4.4 & 40.8 & 53.6 \\
\hline Villa Alemana & 2.5 & 64.4 & 1.4 & 0.3 & 2.6 & 31.3 & 65.8 \\
\hline Viña del Mar & 1.7 & 33.4 & 1.9 & 5.4 & 11.2 & 32.3 & 51.1 \\
\hline Calera & 0.8 & 33.2 & 1.9 & 3.3 & 15.3 & 44.1 & 37.2 \\
\hline La Cruz & 0.2 & 6.2 & 2.1 & 2.4 & 22.8 & 51.3 & 23.6 \\
\hline Concón & 0.1 & 4.6 & 1.4 & 0.0 & 0.7 & 34.3 & 65.0 \\
\hline
\end{tabular}

Observation: The highest four values in each column have been highlighted. Communes highlighted are those with the highest surface area burnt between 1985-2015 (according to both CONAF records and NBR index). 
Finally, non-protected areas were assigned a higher score to reflect the lack of resources available to protect and restore the area in the event of a fire. Within this variable, we have also considered a 50 radius buffer around National Monuments (Biblioteca del Congreso Nacional, 2013) to account for the possible loss of these. Overlapping areas obtain the sum of these scores to reflect the assumption that they have higher environmental value, and thus a fire would result in the damage or loss of more valuable environmental resources.

\subsection{Comparison of the risk index results with past wildfire occurrence}

Because there is no time series of field data available, we opted in quantifying historical occurrence based on remote sensing, through the Nearest Burnt Ratio index. This method has been used in other studies with satisfactory results (Escuin, Navarro, \& Fernández, 2008; Manzo Delgado \& López García, 2013). The precision of the NBR index allows for an accurate detection of areas that were burnt within the last month.

The information was obtained from the processing of LANDSAT images between 1985 and 2015. Each year an image was selected from a summer month (January, February and March). Although the data obtained accounts for only the fires occurred during the summer months and not the whole year, we consider this to be a good representation of the spatial distribution of fires since official data shows that around $75 \%$ of fires occur during the summer (CONAF, 2015). The data obtained from each year was overlaid to obtain cover values representing the number of times the surface was burnt during the study period. This historical fire occurrence cover was contrasted with the fire risk classification.

\section{Results}

\subsection{Risk variables}

The risk variables selected were assigned risk values between 1 and 7 based on their particularities detailed in Table 1 . The results are presented by a cluster of variables (ignition, propagation and impact) in order to better understand their contribution in the final risk map. The classification of the cluster raster layers was done based on 0.5 standard deviation cuts. These maps are shown in Figure 3.

The ignition cluster map shows a greater risk in areas with good road connectivity and even greater in places where the populated area consists of disperse houses rather than large conglomerated urbanized areas. Forest plantations had a significant contribution to the risk level of the coastal, southernmost part of the Valparaíso Region. In wildland areas, far from populated areas that have less road access, the risk level depended mostly on fuel type. Areas with dense forests, dominated by sclerophyllous tree species had a larger impact on the risk quantification. This vegetation type is found mostly on southern-aspect hillsides, whereas north-aspect hillsides are mainly dominated by xerophytic species or less-dense thorny shrublands, and less so by sclerophyllous forest.

For the propagation cluster, mountainous areas that have steep slopes are more favorable to the spreading of fire. In contrast, valleys where permanent streams and bodies of water are found, it is less likely for fire to behave in a dangerous manner. Also these flatter, low-elevation areas are apt for fire combat as the terrain has better accessibility.

Finally, the impact cluster highlights vulnerability elements from the study area. The north-eastern part of the La Campana - Peñuelas BR concentrates both the most vulnerable soils and the vegetation types that are less represented in protected areas. This area is made up of mainly granitic soils that have a high level of desertification and erosion potential. It also concentrates vegetation types that have species in some conservation category such as Prosopis chilensis and Nothofagus macrocarpa.

\subsection{Integration of risk variables and territorial analysis}

The final risk analysis was developed through a combination of all variables with equal weights. The resulting raster layer was re-classified using a 0.5 standard deviation classification to obtain 7 risk classes (Figure 4 and Figure 5).

\subsection{Historical occurrence}

The burnt areas considered in this study had a minimum surface of 10 hectares. The resulting polygons of burnt area during the 1985-2015 period were overlaid to obtain a map of cumulative fires (Figure 6)

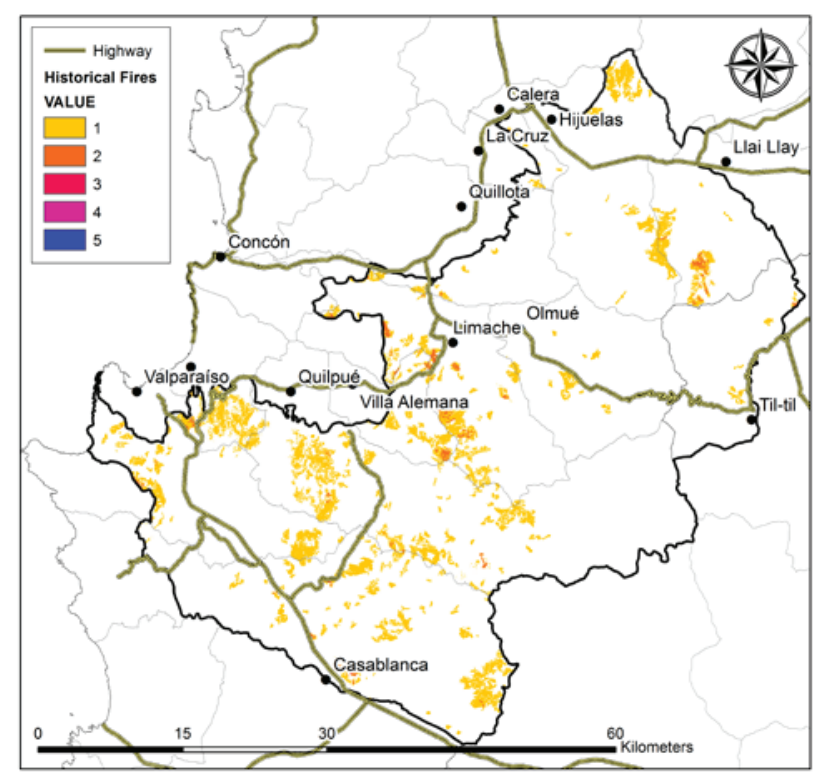

Figure 6. Cumulative fire ocurrence 


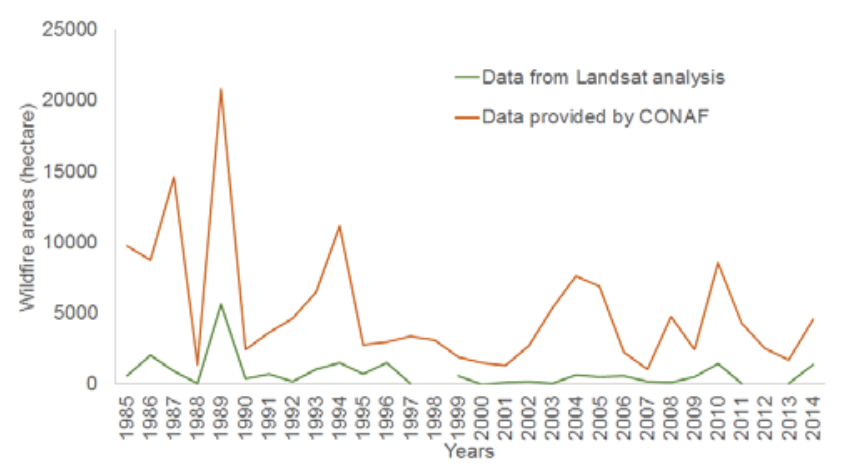

Figure 7. Surface affected by wildfires by historical sources

Given that most wildfires occur in the summer, the historical data obtained from the NBR index comes from images selected during the summer months of each year. Therefore, we can expect these records to represent a significant proportion of all fires occurred during the study period (1985-2015).

The results obtained from the NBR processing show the same trends as the official CONAF records. Both the historical data from CONAF and the NBR show reductions in the surface area burnt and coincide in the years with the greatest amount of area affected by fires, as well as the administrative units most affected (Figure 7). The communes with the greatest surface area burnt according to both records are: Quilpué, Valparaíso, Casablanca and Limache. Difference are given by CONAF data consider the entire administrative units, in turn data extracted from Landsat imagery is restricted to the share of each administrative unit within the $\mathrm{BR}$.

The advantage of the NBR historical data is to visualize the location of the burnt surface within the BR: most of it corresponds to the transition zone, with the exception of the years 1991 and 1999, where there was more burnt area within the buffer zone corresponding to $(55 \%$ and $86 \%$ of all burnt surface). On the other hand, the data from CONAF allows to identify the type of land cover burnt each year. For the communes of interest, the largest area affected corresponds to native vegetation corresponding to ( $87 \%$ on average for the $1985-2015$ period), particularly mediterranean shrubs. However, in the study period, forest plantations of Pinus radiata and Eucalyptus globulus have gained importance, increasing in $10 \%$ of the total area affected by fires.

\subsection{Wildfire risk in relation to historical occurrence}

The comparison between the historical wildfire occurrence data and the composite wildfire risk obtained through the methodology presented above reveals that wildfires have not necessarily occurred in areas which pose the highest risk. From the LANDSAT images analysis, it was derived that $92 \%$ of the La Campana - Peñuelas BR has not been burnt in the past 15 years, and less than $0.5 \%$ has been burnt two or more times. With regards to the wildfire risk classification: $49 \%$ of the BR area has a low wildfire risk (risk class $=1$ ), 9\% has a high risk (risk classes 3 and 4 ) and $4 \%$ has a very high risk (risk classes 5, 6 and 7). The commune presenting the highest average risk class is Til-Til, followed by Olmué, Hijuelas and La Cruz. Olmué and Hijuelas are particularly relevant communes as their territory is completely within the BR and a significant percentage of their surface shows a high and very high wildfire risk.

Despite the low correspondence between historical wildfire occurrence and wildfire risk, the results of the modelling are relevant because they account for a definition of risk that includes both threat and vulnerability of a territory. Threat is a condition generated by external pressures; while vulnerability is an intrinsic condition of the territory. The present fire risk model includes external pressures that are stable over time (such as roads and human settlements), and also intrinsic conditions that make certain areas more vulnerable (such as vegetation cover and soil condition). Knowing that some areas have high vulnerability (and therefore higher risk), but have not historically been burnt many times, can help to account for the high priority of conservation these territories. The model also allows to identify areas that have had strong wildfire pressure over time and also pose high risk, thus should have resources allocated to them for restoration efforts.

\section{Discussion}

Our results respond to the purpose of offering an alternative to quantify risk and identify the sectors that are more exposed within the La Campana - Peñuelas Biosphere Reserve. The advantage of developing a site-specific wildfire risk index is that through the selection of relevant risk variables, a more precise risk estimation can be obtained according to the particularities of each territory (Mitsopoulos et al., 2014). Mediterranean ecosystems of the world share being highly associated with urban areas and conditioned by social factors that increase the vulnerability to wildfires. Thus, the implementation of ideas and methods in Chile is transferable to other Mediterranean areas, especially related to the impact of highly valuable vegetation types.

For Central Chile, Altamirano, Salas, Yaitul, SmithRamirez, and Ávila (2013) developed a logistical regression model and used maximum likelihood adjustments to select 3 explanatory variables out of 14 variables analyzed, to explain the probability of wildfire occurrence. The selected variables were minimum temperature for the coldest month, precipitation seasonality and distance from cities. Climatic variables are key in determining the probability of occurrence, since they greatly affect the conditions of fuel load. In the present work, we opted in using structural variables that don't change much throughout the seasons or years. A model of wildfire probability occurrence differs from risk quantification, mainly because the latter incorporates threat (external factors that facilitate ignition) as well as vulnerability (intrinsic characteristics of the territory that are predisposed to a higher negative impact). 
With regards to the method used for historical occurrence quantification, it is worth mentioning that in order to account for the entire spatial-temporal distribution of all fires, it would be necessary to process images from other seasons as well (spring, winter and autumn). Nevertheless, the data obtained is a good representation of the historical occurrence of fires in the study period as they have a similar tendency when compared to the official historical data from the National Forest Corporation (CONAF). Also, the burnt area quantified using the NBR index accounts for the season when most of the fires occur (around 75\% of fires occur in the summer).

Some additional improvements to our work, aside from the application of NBR processing to autumn, winter and spring images, would be to incorporate fuel type variation throughout the year. The conditions of combustible vegetative material, especially its water content, have a direct relation with the probability of ignition and propagation of a fire. Humidity in live and dead vegetation varies significantly throughout the year, and even throughout the day. Some authors have accounted for this variation, detecting that the importance of the water content in vegetation is higher in spring and lower in autumn (Ager et al., 2014). Other authors have conducted focalized studies to determine the specific flammability of different vegetation types. They have done this using a combination of climatic data, such as surface temperature, and the Normalized Differential Vegetation Index (Chuvieco et al., 2004). There are no studies conducted in Chile that account for this variation, let al.ne studies that use climatic data to reflect projections of climate change to model fuel load. In addition, the use of the MODIS products is highly valuable. Even though they are available only from 2000 to date, they allow to analyse very extensive areas including data of different seasons, a quality band to correct the data provided and very well developed algorithms to identify burned areas (e.g. Giglio et al., 2010; Darques, 2015, 2016; Giglio, Schroeder, \& Justice, 2016; Levin et al., 2016).

The approach to quantifying risk in the present work aimed to contribute concrete information for decision making. There is some experience in Chile with ecological restoration of native forests affected by wildfires (Fernández et al., 2010), so identifying the areas that are more threatened and vulnerable to fires could help allocate resources for restoration more efficiently. Another application of risk analysis is to improve the infrastructure and coverage of wildfire control. By using network analysis of geographic information systems, the service areas for existing firefighting stations can be determined thus identifying those areas with less coverage and those more exposed to fire damage. This type of land-cover firefighting is different from aerial firefighting. In order to account for the aerial fire-fighting capacity, the quantification of the service-areas should be based on direct distance travel times.

The current fire modeling and alert system for CONAF is called Kitral and mostly deals with economic efficiency in firefighting (Pedernera \& Julio, 1999). This system feed the alerts provided by inhabitants and practitioners of the Ministry of Agriculture and the office for emergencies of the Ministry of Interior. Some areas have towers of observation, especially in protected areas and forestry plantations. We suggest that incorporating ecological and social variables could improve the detection of vulnerable areas and increase the options for early detection of wildfires and timely combat.

Finally, we hope our results contribute to territorial planning at the level where management objectives and strategies on different scales are defined, including management instruments such as Commune Plans, Intercommunal Regulatory Plans, National and Regional Biodiversity Strategies and Management Plans for Protected Areas. Stephens, Millar, and Collins (2010) have proposed strategies grouped in resistance, resilience, response, and strategic alignment, all of which are oriented towards the persistence of the species on an ecoregion scale.

The areas identified with highest risk are not necessarily those that have historically been more affected by wildfires. This should alert decision-makers to focus resources for fire prevention in these areas. Identifying the risk areas can beneficial for environmental protection, because burned areas contribute to increase water erosion risks, which is especially important in semiarid zones (Norzagaray-Campos et al., 2016) and in hilly landscapes that contain large extensions of agricultural lands (Jarašiūnas \& Kinderiené, 2016). Therefore, wildfire prevention should be motivated not only to avoid the loss of constructions and valuable ecosystems, but also to avoid hazards like flooding or landslides.

\section{Conclusions}

Fires like others processes that modify ecosystems everywhere will be affected by global climate change. We cannot rely fully on past climate conditions to develop future management plans. In order to respond to uncertainty, it is imperative for decision makers to integrate adaptation strategies in their plans in response to climate change. The current Management Plan for the La Campana Biosphere Reserve has no specific considerations on fire occurrence or risk. The UNESCO Man and the Biosphere Program proposes that Biosphere Reserve Management Plans should be revised periodically every 10 years. The Management Plan for the La Campana - Peñuelas BR should be revised and updated soon. We hope this fire risk analysis contributes to a better understanding of a region of global biodiversity importance and provides empirical information for the optimal and sustainable management of this Biosphere Reserve in the future. The results of this research highlight the need to destine resources to fire prevention in valuable landscapes and develop adaptation strategies for risk management and environmental protection at different scales. 


\section{Acknowledgements}

The authors want to thank the collaboration of Andrés Moreira-Muñoz and Camilo del Río in preliminary phases of the research, and the suggestions from anonymous reviewers. The research was funded by CONICYT/FONDECYT 1150422 and supported by CONICYT/FONDAP 15110020.

\section{References}

Ager, A., Preisler, H., Arca, B., Spano, D., \& Salis, M. (2014). Wildfire risk estimation in the mediterranean area. Environmetrics, 25(6), 384-396. https://doi.org/10.1002/env.2269

Alloza, J., Baeza, M., De la Riva, J., Duguy, B., Echeverría, M., Ibarra, P., Llovet, J., Pérez-Cabello, F., Rovira, P., Vallejo, V. (2006). A model to evaluate the ecological vulnerability to forest fires in mediterranean ecosystems. Forest Ecology and Management, 234(Supplement), S203.

https://doi.org/10.1016/j.foreco.2006.08.322

Altamirano, A., Salas, C., Yaitul, V., Smith-Ramirez, C., \& Ávila, A. (2013). Influencia de la heterogeneidad del paisaje en la ocurrencia de incendios forestales en Chile Central. Revista de Geografía Norte Grande, 170(55), 157-170.

https://doi.org/10.4067/S0718-34022013000200011

Arca, B., Duce, P., Laconi, M., Pellizzaro, G., Salis, M., \& Spano, D. (2007). Evaluation of FARSITE simulator in Mediterranean maquis. International Journal Wildland Fire, 16(5), 563572. https://doi.org/10.1071/WF06070

Aretano, R., Semeraro, T., Petrosillo, I., De Marco, A., Pasimeni, M. R., \& Zurlini, G. (2015). Mapping ecological vulnerability to fire for effective conservation management of natural protected areas. Ecological Modelling, 295, 163-175. https://doi.org/10.1016/j.ecolmodel.2014.09.017

Bajocco, S., \& Ricotta, C. (2008). Evidence of selective burning in Sardinia (Italy): which land-cover classes do wildfires prefer?. Landscape Ecology, 23(2), 241-248. https://doi.org/10.1007/s10980-007-9176-5

Bhandary, U., \& Muller, B. (2009). Land use planning and wildfire risk mitigation: an analysis of wildfire-burned subdivisions using high-resolution remote sensing imagery and GIS data. Journal of Environmental Planning and Management, 52(7), 939-955. https://doi.org/10.1080/09640560903181147

Biblioteca del Congreso Nacional (BCN). (2010). Ley 19.300 Sobre Bases Generales del Medio Ambiente. Ministerio Secretaría General de la Presidencia.

Biblioteca del Congreso Nacional (BCN). (2013). Ley 17.288 Legisla Sobre Monumentos Nacionales. Ministerio de Educación.

Biblioteca del Congreso Nacional (BCN). (2014a). Decreto Supremo 29/2014 Aprueba Reglamento para la Clasificación de Especies Silvestres según Estado de Conservación. Ministerio del Medio Ambiente.

Biblioteca del Congreso Nacional (BCN). (2014b). Decreto Supremo 52/2014 Aprueba y oficializa clasificación de especies según su estado de conservación, décimo proceso. Ministerio del Medio Ambiente.

Biblioteca del Congreso Nacional (BCN). (2014c). Ley 18.362 Crea Sistema Nacional de Áreas Silvestres Protegidas del Estado. Ministerio de Agricultura.

Borsdorf, A., \& Rosas, P. A. (2014). El modelo de Reservas de la Biosfera: conceptos, características e importancia. In Reservas de la Biosfera de Chile - Laboratorio para la Sustentabilidad (pp. 4-20).
Carmona, A., González, M. E., Nahuelhual, L., \& Silva, J. (2012). Spatio-temporal effects of human drivers on fire danger in mediterranean Chile. Bosque, 33(3), 31-32. https://doi.org/10.4067/S0717-92002012000300016

Castillo, M., Molina, J., Rodríguez y Silva, F., \& Alvear, G. (2013). A territorial fire vulnerability model for Mediterranean ecosystems in South America. Ecological Informatics, 13, 106113. https://doi.org/10.1016/j.ecoinf.2012.06.004

Castillo, M., Quintanilla, V., \& Julio, G. (2009). Análisis del riesgo y vulnerabilidad contra incendios forestales en áreas de interfaz, provincia de Valparaíso. Territorium, 16, 131-138.

Centro de Información de Recursos Naturales (CIREN). (2010a). Determinación de la erosión actual y potencial de los suelos de Chile. Región de Valparaíso. Ministerio de Agricultura.

Centro de Información de Recursos Naturales (CIREN). (2010b). Determinación de la erosión actual y potencial de los suelos de Chile. Región Metropolitana. Ministerio de Agricultura.

Chuvieco, E., \& Kasischke, E. S. (2007). Remote sensing information for fire management and fire effects assessment. Journal of Geophysical Research, 112(G1), 1-8. https://doi.org/10.1029/2006JG000230

Chuvieco, E., Cocero, D., Riaño, D., Martin, P., Martínez, J., De La Riva, J., \& Pérez, F. (2004). Combining NDVI and surface temperature for the estimation of live fuel moisture content in forest fire danger rating. Remote Sensing of Environment, 92(3), 322-331. https://doi.org/10.1016/j.rse.2004.01.019

Comisión Nacional del Medio Ambiente (CONAMA). (2005). Plan de Acción País para la Implementación de la Estrategia Nacional de Biodiversidad 2004-2015.

Comisión Nacional del Medio Ambiente (CONAMA). (2008). Plan de Acción Integrado de Biodiversidad 2007-2010, 1-43.

Comité Nacional Pro Defensa de la Fauna y Flora (CODEFF). (1999). Las Áreas Silvestres Protegidas Privadas en Chile.

Consejo de Monumenos Nacionales (CMN). (2010). Santuarios de la Naturaleza de Chile. Ó. Acuña, M. S. Silva, L. López, K. Sánchez, E. Bahamondes, R. Otero, \& M. C. Grandi (Eds.). Santiago, Chile: Impresora Óptima S.A.

Corporación Nacional Forestal (CONAF). (2015). Ocurrencia y daño por comuna. Santiago, Chile.

Cowling, R. M., Rundel, P. W., Lamont, B. B., Arroyo, M. K., \& Arianoutsou, M. (1996). Plant diversity in mediterranean-climate regions. Trends in Ecology and Evolution, 11(9), 362-366. https://doi.org/10.1016/0169-5347(96)10044-6

Darques, R. (2015). Mediterranean cities under fire. A critical approach to the wildland-urban interface. Applied Geography, 59, 10-21. https://doi.org/10.1016/j.apgeog.2015.02.008

Darques, R. (2016). Wildfires at a Pan-Mediterranean scale: $\mathrm{Hu}-$ man-environment dynamics through MODIS data. Human Ecology, 44(1), 47-63. https://doi.org/10.1007/s10745-015-9802-9

De Vicente, F. (2012). Diseño de un modelo de riesgo integral de incendios forestales mediante técnicas multicriterio y su automatización en sistemas de información geográfica. Una aplicación en la comunidad Valenciana. Universidad Politécnica de Madrid.

Duguy, B., Alloza, J. A., Baeza, M. J., De La Riva, J., Echeverría, M., Ibarra, P., Llovet, J., Pérez-Cabello, F., Rovira, P., Vallejo, R. V. (2012). Modelling the ecological vulnerability to forest fires in mediterranean ecosystems using geographic information technologies. Environmental Management, 50(6), 1012-1026. https://doi.org/10.1007/s00267-012-9933-3

Escuin, S., Navarro, R., \& Fernández, P. (2008). Fire severity assessment by using NBR (Normalized Burn Ratio) and NDVI (Normalized Difference Vegetation Index) derived from 
LANDSAT TM/ETM images. International Journal of Remote Sensing, 29(4), 1053-1073.

https://doi.org/10.1080/01431160701281072

Fernández, I., Morales, N., Olivares, L., Salvatierra, J., Gómez, M., \& Montenegro, G. (2010). Restauración ecológica para ecosistemas nativos afectados por incendios forestales. Gráfica LOM, Santiago, Chile. 162 pp.

Fox, D., Martin, N., Carrega, P., Andrieu, J., Adnès, C., Emsellem, K., Ganga, O., Moebius, F., Tortorollo, N., Fox, E. (2015). Increases in fire risk due to warmer summer temperatures and wildland urban interface changes do not necessarily lead to more fires. Applied Geography, 56, 1-12.

https://doi.org/10.1016/j.apgeog.2014.10.001

Frau, C. M., Valenzuela, G. J., Rojas, O. Y., Hernádez, Y. M., \& Guajardo, R. M. (2006). Teledetección y SIG en el Ámbito Forestal: Experiencias en Chile. Ambiência, 2, 171-185.

Galiana, L., \& Karlsson, O. (2012). Development of a methodology for the assessment of vulnerability related to wildland fires using a multi-criteria evaluation. Geographical Research, 50(3), 304-319. https://doi.org/10.1111/j.1745-5871.2011.00718.x

Giglio, L., Randerson, J. T., Van der Werf, G. R., Kasibhatla, P. S., Collatz, G. J., Morton, D. C., \& DeFries, R. S. (2010). Assessing variability and long-term trends in burned area by merging multiple satellite fire products. Biogeosciences, 7(3), 1171-1186. https://doi.org/10.5194/bg-7-1171-2010

Giglio, L., Schroeder, W., \& Justice, C. O. (2016). The collection 6 MODIS active fire detection algorithm and fire products. Remote Sensing of Environment, 178, 31-41. https://doi.org/10.1016/j.rse.2016.02.054

Gill, A. M., Stephens, S. L., \& Cary, G. J. (2013). The worldwide "wildfire" problem. Ecological Applications, 23(2), 438-454. https://doi.org/10.1890/10-2213.1

Herrero, G., Jappiot, M., Bouillon, C., \& Long, M. (2012). Application of a geographical assessment method for the characterization of wildland-urban interfaces in the context of wildfire prevention: A case study in western Madrid. Applied Geography, 35(1-2), 60-70.

https://doi.org/10.1016/j.apgeog.2012.05.005

Hessburg, P. F., Reynolds, K. M., Keane, R. E., James, K. M., \& Salter, R. B. (2007). Evaluating wildland fire danger and prioritizing vegetation and fuels treatments. Forest Ecology and Management, 247(1-3), 1-17.

https://doi.org/10.1016/j.foreco.2007.03.068

Huesca, M., Litago, J., Merino-de-Miguel, S., Cicuendez, V., \& Palacios, A. (2014). Modeling and forecasting MODIS-based Fire Potential Index on a pixel basis using time series models. International Journal of Applied Earth Observation and Geoinformation, 26, 363-376.

https://doi.org/10.1016/j.jag.2013.09.003

Ireland, G., \& Petropoulos, G. P. (2015). Exploring the relationships between post-fire vegetation regeneration dynamics, topography and burn severity: A case study from the Montane Cordillera Ecozones of Western Canada. Applied Geography, 56, 232-248. https://doi.org/10.1016/j.apgeog.2014.11.016

Jarašiūnas, G., \& Kinderienè, I. (2016). Impact of agro-environmental systems on soil erosion processes and soil properties on hilly landscape in Western Lithuania. Journal of Environmental Engineering and Landscape Management, 24(1), 60-69. https://doi.org/10.3846/16486897.2015.1054289

Julio, G. (1990). Diseño de índices de riesgo de incendios forestales para Chile. Bosque, 11(2), 59-72. https://doi.org/10.4206/bosque.1990.v11n2-06

Lampin-Maillet, C., Long, M., Ganteaume, A., Jappiot, M., \& Ferrier, J. (2011). Land cover analysis in wildland-urban in- terfaces according to wildfire risk: A case study in the South of France. Forest Ecology and Management, 261(12), 22002213. https://doi.org/10.1016/j.foreco.2010.11.022

Levin, N., Tessler, N., Smith, A., \& McAlpine, C. (2016). The human and physical determinants of wildfires and burnt areas in Israel. Environmental Management, 58(3), 549-562. https://doi.org/10.1007/s00267-016-0715-1

Luebert, F., \& Pliscoff, P. (2017). Sinopsis Bioclimática y Vegetacional de Chile. Segunda edición. Editorial Universitaria, Santiago.

Manzo Delgado, L., \& López García, J. (2013). Detección de áreas quemadas en el sureste de México, utilizando índices pre y post-incendio NBR y BAI, derivados de compuestos MODIS. Geofocus, Revista Internacional de Ciencia Y Tecnología de La Información Geográfica, (13-2), 66-83.

Ministerio del Medio Ambiente (MMA). (2011). Diseño del Inventario Nacional de Humedales y el Seguimiento Ambiental. Ministerio del Medio Ambiente, Chile. 164 p. Retrieved from http://www.mma.gob.cl/1304/articles-50507_documento.pdf

Ministerio del Medio Ambiente (MMA). (2013). Acta Sesión 1 Décimo Proceso Clasificación. Comité Clasificación de Especies Silvestres.

Mitsopoulos, I., Mallinis, G., \& Arianoutsou, M. (2014). Wildfire risk assessment in a typical Mediterranean wildland-urban interface of Greece. Environmental Management, 55(4), 900915. https://doi.org/10.1007/s00267-014-0432-6

Moreira, A., \& Troncoso, J. (2014). Representatividad biogeográfica de las Reservas de la Biosfera de Chile. In Reservas de la Biósfera de Chile - Laboratorios para la Sustentabilidad (pp. 24-61).

Muñoz, M., Núñez, H., \& Yáñez, J. (1997). Libro rojo de los sitios prioritarios para la conservación de la biodiversidad en Chile. Ambiente Y Desarrollo, 13(2), 90-99.

Myers, N., Mittermeier, R. A., Mittermeier, C. G., da Fonseca, G. A. B., \& Kent, J. (2000). Biodiversity hotspots for conservation priorities. Nature, 403(6772), 853-858. https://doi.org/10.1038/35002501

Norzagaray-Campos, M., Muñoz-Sevilla, P., EspinosaCarreón, L., Ruíz-Guerrero, R., González-Ocampo, H., \& Llanes-Cárdenas, O. (2016). Erosivity indicators based on rainfall in Northwestern Mexico. Journal of Environmental Engineering and Landscape Management, 24(2), 133-142. https://doi.org/10.3846/16486897.2015.1106405

Pedernera, P., \& Julio, G. (1999). Improving the economic efficiency of combatting forest fires in Chile: The KITRAL system. Proceedings of Symposium on Fire Economics, Planning and Policy: Bottom Lines, 173, 149-155.

Pourtaghi, Z. S., Pourghasemi, H. R., \& Rossi, M. (2015). Forest fire susceptibility mapping in the Minudasht forests, Golestan province, Iran. Environmental Earth Sciences, 73(4), 15151533. https://doi.org/10.1007/s12665-014-3502-4

Saglam, B., Bilgili, E., Dincdurmaz, B., Kadiogulari, A. I., \& Kücük, Ö. (2008). Spatio-temporal analysis of forest fire risk and danger using LANDSAT imagery. Sensors, 8(6), 39703987. https://doi.org/10.3390/s8063970

Salazar, A., \& Moreira, A. (2014). Reserva de la Biosfera La Campana - Peñuelas: micro-región modelo para la planificación del desarrollo regional sustentable. In Reservas de la Biosfera de Chile - Laboratorios para la Sustentabilidad (pp. 106-122).

Salazar, A., Moreira, A., \& Río, C. (2015). La Campana-Peñuelas Biosphere Reserve in Central Chile: threats and challenges in a peri-urban transition zone. Management and Policy Issues, 7(1), 49-54.

Salis, M., Ager, A., Finney, M., Arca, B., \& Spano, D. (2014). Analyzing spatiotemporal changes in wildfire regime and expo- 
sure across a Mediterranean fire-prone area. Natural Hazards, 71(3), 1389-1418. https://doi.org/10.1007/s11069-013-0951-0

Salvati, L., \& Ferrara, A. (2014). Do land cover changes shape sensitivity to forest fires in peri-urban areas?. Urban Forestry and Urban Greening, 13(3), 571-575.

https://doi.org/10.1016/j.ufug.2014.03.004

Sivrikaya, F., Sağlam, B., Akay, A. E., \& Bozali, N. (2014). Evaluation of forest fire risk with GIS. Polish Journal of Environmental Studies, 23(1), 187-194.

Stephens, S. L., Millar, C. I., \& Collins, B. M. (2010). Operational approaches to managing forests of the future in Mediterranean regions within a context of changing climates. Environmental Research Letters, 5(2), 024003. https://doi.org/10.1088/1748-9326/5/2/024003

Úbeda, X., \& Sarricolea, P. (2016). Wildfires in Chile: A review. Global and Planetary Change, 146, 152-161. https://doi.org/10.1016/j.gloplacha.2016.10.004

UNESCO. (2015). Man and the Biosphere Programme. Retrieved from http://www.unesco.org/new/en/natural-sciences/en- vironment/ecological-sciences/man-and-biosphere-programme/

Van Wilgen, B., le Maitre, D., \& Kriger, F. (1985). Fire modeling in South African fynbos (macchia) vegetation and predictions from Rothermels fire model. Applied Ecology, 22(1), 207-213. https://doi.org/10.2307/2403338

Venegas, F. (2015). Falta de planificación y política economicista amenazan la Reserva Mundial de la Biósfera La CampanaPeñuelas. El Observador. Santiago, Chile.

Verbesselt, J., Fleck, S., \& Coppin, P. (2002). Estimation of fuel moisture content towards Fire Risk Assessment: A review. In D. X. Viegas, M. G. Cruz, L. M. Silva, A. J. Ollero (Eds.). Forest fire research \& wildland fire safety, (pp. 55-67). Rotterdam: Millpress.

Viedma, O. (2008). The influence of topography and fire in controlling landscape composition and structure in Sierra de Gredos (Central Spain). Landscape Ecology, 23(6), 657-672. https://doi.org/10.1007/s10980-008-9228-5 